\title{
In Vitro Performance of Bioinspired Phenolic Nanocoatings for Endosseous Implant Applications
}

\author{
Sebastian Geißler ${ }^{\mathrm{a}, \dagger}$, Manuel Gomez-Florit ${ }^{\mathrm{a}, \dagger, 1}$, David Wiedmer ${ }^{\mathrm{a}}$, Alejandro Barrantes ${ }^{\mathrm{a}}$ \\ Fernanda C. Petersen ${ }^{\mathrm{b}}$, and Hanna Tiainen ${ }^{\mathrm{a}, *}$
}

\begin{abstract}
${ }^{a}$ Department of Biomaterials, Institute of Clinical Dentistry, University of Oslo, P.O. box 1109 Blindern, 0317 Oslo, Norway

${ }^{b}$ Department of Oral Biology, Faculty of Dentistry, University of Oslo, P.O. box 1052 Blindern, 0316 Oslo, Norway

${ }^{\dagger}$ The authors contributed equally to this study and should both be considered as first author

*Corresponding author: hanna.tiainen@odont.uio.no
\end{abstract}

\begin{abstract}
In the quest for finding new strategies to enhance tissue integration and to reduce the risk of bacterial colonisation around endosseous implants, we report the application of auto-oxidative phenolic coatings made of tannic acid and pyrogallol to titanium surfaces. The functionalised surfaces were screened for their biological performance using cultures of primary human osteoblasts and biofilm-forming bioluminescent staphylococci S. epidermidis Xen43 and S. aureus Xen29. No toxic effect of the coatings on osteoblasts was detected. While tannic acid coatings seemed to induce a delay in osteoblast maturation, they revealed anti-inflammatory potential. Similar effects were observed for pyrogallol coatings deposited for $24 \mathrm{~h}$. Thin pyrogallol coatings deposited for $2 \mathrm{~h}$ seemed to promote osteoblast maturation and revealed increased calcium deposition. The effects on osteoblast were found to be related to the release of phenolic compounds from the surfaces. While the phenolic coatings could not inhibit
\end{abstract}

\footnotetext{
${ }^{1}$ Present address: 3B's Research Group, I3B's - Research Institute on Biomaterials, Biodegradables and Biomimetics, University of Minho, Guimarães, Portugal
} 
staphylococcal biofilm formation on the titanium surfaces, released phenolic compounds had an inhibitory effect the growth of planktonic bacteria. In conclusion, the assessed coating systems represent a versatile functionalisation method which exhibit promising effects for endosseous implant applications.

Keywords: implant, polyphenols, tannic acid, biofilm, staphylococcus

\section{Introduction}

The performance of bone-anchored implants, such as orthopaedic or dental implants, is highly dependent on the early events taking place at the implant-tissue interface. Ideally, undisturbed peri-implant healing leads to a stable integration of the implant in the surrounding bone tissue, ensuring a long-lasting function of the implant. However, there are several factors influencing the peri-implant bone healing process, such as bone type, implantation location, the extent of induced trauma, or the degree of initial implant fixation. ${ }^{1}$ Moreover, bone healing can be compromised in the presence of systemic diseases or other risk factors, such as smoking or radiation therapy. ${ }^{2-5} \mathrm{~A}$ further factor that may contribute to an unsuccessful implantation outcome is the occurrence of biomaterial-associated infections caused by bacteria, which enter the implantation site and form a biofilm on the implant surface..$^{6-8}$

Particularly in such situations where bone healing is impaired and the infection risk is high, there is a desire to influence the implant-tissue interface in a way that host tissue integration is promoted and bacterial colonisation is prevented. Changing the properties of the implant surface belongs to the most common strategies to improve bone tissue integration. ${ }^{9}$ Traditionally, this has been achieved by altering the surface micro- and nanoscale topography (e.g. by grit-blasting and acid-etching), by coating the implant surface with calcium phosphates, or by anodising the surface. ${ }^{10-13}$ More recent approaches have focused on the 
immobilisation of bioactive molecules, such as extracellular matrix proteins, RGD-containing peptides, growth factors, or antimicrobial agents, onto the implant surface to help evoking the desired implant-tissue interaction. ${ }^{14-17}$

Over the past few years, the use of universal coating systems to functionalise biomaterial surfaces has attracted increasing attention. ${ }^{18-21}$ Beside the intensively studied mussel-inspired polydopamine system, ${ }^{22-24}$ these coating systems also include a group of plant-derived compounds rich in functional catechol and gallol groups. Several of such polyphenols and phenolic compounds have been demonstrated to form multifunctional adhesive coatings on a diverse range of materials via auto-oxidative surface polymerisation. ${ }^{25-27}$ In particular, coatings based on tannic acid (TA) and pyrogallol (PG) have been reported to exhibit antioxidant and antibacterial properties, ${ }^{25}$ making them promising candidates for biofilm-resistant surface coatings of biomedical implants.

With the motivation of using these functional polyphenol coatings to design cell-adhesive and antibacterial surfaces for endosseous implants, the present study aimed at investigating the effect of auto-oxidative TA and PG coatings on human osteoblasts (hOBs). In addition, the antibacterial activity of the coatings was tested in a bacterial assay using Staphylococcus epidermidis and Staphylococcus aureus. Since our recent study demonstrated that the structural properties of TA and PG coatings were dependent on the coating time, and thus, the coating thickness ${ }^{28}$ the tests in this work were performed on both thin $(10-30 \mathrm{~nm})$ and thick $(60-$ $80 \mathrm{~nm}$ ) coatings.

\section{Materials and methods}

\subsection{Sample preparation}

Grade IV commercially pure titanium discs with a diameter of $6.2 \mathrm{~mm}$ and a height of $2 \mathrm{~mm}$ were mirror-polished and washed as described previously, ${ }^{29}$ and autoclaved for $20 \mathrm{~min}$ at 
$121^{\circ} \mathrm{C}$. All chemicals for coating preparation were purchased from Sigma-Aldrich. Tannic acid and pyrogallol were of ACS reagent grade. The coating buffer for TA was made of $0.1 \mathrm{M}$ bicine containing $0.6 \mathrm{M} \mathrm{NaCl}$. For PG coatings, the coating buffer consisted of $0.1 \mathrm{M}$ bis-tris containing $0.1 \mathrm{M} \mathrm{MgCl}_{2}$. The $\mathrm{pH}$ of the coating buffer was adjusted to 7.8 for TA and 7.0 for PG. The phenolic compounds were dissolved in the coating buffers at a concentration of 1 $\mathrm{mg} / \mathrm{ml}(0.6 \mathrm{mM}$ for TA and $7.9 \mathrm{mM}$ for PG) and the coating solutions were filter-sterilised using sterile $0.2 \mu \mathrm{m}$ syringe filters. Coatings were produced by immersing the substrates in the coating solutions for either $2 \mathrm{~h}$ (TA2 and PG2; thin coatings) or $24 \mathrm{~h}$ (TA24 and PG24; thick coatings) at room temperature while shaking on a rocking platform at 30 oscillations per minute. The coated substrates were thereafter thoroughly rinsed with deionised (DI) $\mathrm{H}_{2} \mathrm{O}$ and dried under nitrogen flow. Unmodified titanium discs (Ti) were used as control surfaces.

\subsection{Coating stability test}

The stability of the coatings was tested using a quartz crystal microbalance with dissipation monitoring (QCM-D, Q-Sense E4, Biolin Scientific AB, Stockholm, Sweden). TA and PG coatings were deposited on titanium coated quartz crystals (QXS 310, Biolin Scientific) using a flow system described previously. ${ }^{28}$ Briefly, the coating solutions were stirred at $100 \mathrm{rpm}$ outside the instrument while being pumped over the quartz crystal at room temperature using a flow rate of $100 \mu \mathrm{l} / \mathrm{min}$. After either $2 \mathrm{~h}$ or $24 \mathrm{~h}$ of coating deposition, the coated crystals were first rinsed with coating buffer, followed by rinsing with phosphate buffered saline (PBS; $\mathrm{pH}=7.4$ ) at $37^{\circ} \mathrm{C}$ for $12 \mathrm{~h}$. After this, a final rinsing step with coating buffer was applied. During the whole experiment, the changes in resonance frequency were monitored.

\subsection{Cell study}




\subsubsection{Cell culture}

Human osteoblasts (Lonza, Basel, Switzerland) were cultured in osteoblast basal medium supplemented with OGM-SingleQuots (Lonza), containing $10 \%$ fetal bovine serum, $0.1 \%$ amphotericin/gentamicin and $145 \mu \mathrm{M}$ ascorbic acid. Cells were routinely cultured at $37^{\circ} \mathrm{C} / 5 \%$ $\mathrm{CO}_{2}$ and were subcultured before reaching confluence using trypsin/EDTA, as recommended by the supplier. Trypan blue stain was used to determine total and viable cell number. Experiments were performed with cells at passages 5 to 7 after isolation.

Samples were placed in 96-well plates and $7.0 \times 10^{3}$ cells were seeded on each well $(n=6$, unless otherwise specified). Culture media was supplemented with $200 \mathrm{nM}$ hydrocortisone, and after evidence of cell multilayering, with $10 \mathrm{mM} \beta$-glycerophosphate.

\subsubsection{Cytotoxicity}

Lactate dehydrogenase (LDH) activity in the culture media $48 \mathrm{~h}$ after seeding was used as an index of cytotoxicity. LDH activity was determined spectrophotometrically after 30 min incubation at $25^{\circ} \mathrm{C}$ of $100 \mu \mathrm{l}$ of culture and $100 \mu \mathrm{l}$ of the reaction mixture by measuring the oxidation of $\mathrm{NADH}$ at $490 \mathrm{~nm}$ in the presence of pyruvate, according to the kit instructions from the manufacturer (Roche Diagnostics, Mannheim, Germany). Results are presented relative to the LDH activity in the medium of cells seeded on Ti (low control, $0 \%$ of cell death) and on plastic adding $1 \%$ Triton $\mathrm{X}-100$ (high control, $100 \%$ of death), using the equation: Cytotoxicity $(\%)=($ exp.value - low control $) /($ high control - low control $) \times 100$.

\subsubsection{Cell morphology}

Cells grown for $48 \mathrm{~h}$ on the surfaces were fixed for $15 \mathrm{~min}$ with $4 \%$ formaldehyde in PBS. For actin cytoskeleton visualisation, cells were stained for $30 \mathrm{~min}$ with $5 \mu \mathrm{g} / \mathrm{ml}$ phalloidin Alexa Fluor 488 (Life Technologies, Carlsbad, CA, USA) with $0.2 \%$ Triton X-100 in PBS. Then, nuclei were stained with DAPI (Sigma-Aldrich) for 5 min. A drop of mounting media was 
added and cover glasses were mounted on the samples. Two samples of each group were used to perform the experiment and two images of each sample were taken with a Leica SP8 upright confocal laser scanning microscope (CLSM; Leica, Wetzlar, Germany) with 40×/1.30 HC PL APO CS2 objective using $405 \mathrm{~nm}$ and $488 \mathrm{~nm}$ excitation wavelengths for DAPI and phalloidin, respectively.

\subsubsection{Metabolic activity}

Reduction of resazurin to resorufin by cellular respiration was used as a measure of the metabolic activity of cells cultured on the sample surfaces. After 2 and 6 days of cell culture, $20 \mu \mathrm{l}$ of PrestoBlue (Life Technologies) in $200 \mu \mathrm{l}$ of fresh culture media was added to cells and the cells were incubated for $1 \mathrm{~h}$ at $37^{\circ} \mathrm{C} / 5 \% \mathrm{CO}_{2}$ with the reagent. Metabolic activity was then determined by reading the absorbance of the culture media at 570 and $600 \mathrm{~nm}$, following manufacturer's protocol.

\subsubsection{Gene expression analysis}

After 7 and $14 \mathrm{~d}$ of cell culture, total RNA was isolated using guanidinium thiocyanate-phenolchloroform extraction (Trizol, Life Technologies) according to the manufacturer's protocol. Total RNA was quantified at $260 \mathrm{~nm}$ using a NanoDrop spectrophotometer. The same amount of RNA $(0.2 \mu \mathrm{g})$ was reverse transcribed to cDNA at $42^{\circ} \mathrm{C}$ for $60 \mathrm{~min}$, according to the protocol from the supplier (First Strand cDNA Synthesis Kit, Thermo Scientific, Waltham, MA, USA). Each cDNA sample was diluted 1:7 and aliquots were frozen $\left(-20^{\circ} \mathrm{C}\right)$ until the PCR reactions were carried out.

Real-time PCR was performed for the target genes and two reference genes (Table S1, supporting information). Real-time PCR was performed in a thermocycler (CFX96, Bio-Rad, Hercules, CA, USA) using SYBR green detection. Each reaction contained $7 \mu$ of master mix (Q-SYBR, Green Supermix, Bio-Rad), $0.5 \mu \mathrm{M}$ of the sense and the antisense specific primers 
each, and $3 \mu \mathrm{l}$ of the cDNA dilution in a final volume of $10 \mu \mathrm{l}$. The amplification programme consisted of a pre-incubation step for denaturation of the template cDNA $\left(5 \min\right.$ at $\left.95^{\circ} \mathrm{C}\right)$, followed by 45 cycles consisting of a denaturation step $\left(10 \mathrm{~s}\right.$ at $\left.95^{\circ} \mathrm{C}\right)$, an annealing step $(10 \mathrm{~s}$ at $\left.60^{\circ} \mathrm{C}\right)$ and an extension step $\left(10 \mathrm{~s}\right.$ at $\left.72^{\circ} \mathrm{C}\right)$. After each cycle, fluorescence was measured at $72^{\circ} \mathrm{C}$. A negative control without cDNA template was run in each assay. All samples were normalised by the geometric mean of the expression levels of reference genes and fold changes were related to the control groups using the following equation: ratio $=\mathrm{E}_{\text {target }} \Delta \mathrm{Cp}$ target (mean control -sample) $/ \mathrm{E}_{\text {reference }} \Delta \mathrm{Cp}$ reference (mean control-sample) , where $\mathrm{Cp}$ is the is the crossing point of the reaction amplification curve and E the efficiency from the given slopes using serial dilutions, as determined by the software (CFX Manager, Bio-Rad). Stability of reference genes was calculated using a statistical tool (BestKeeper software, Technical University of Munich, Weihenstephan, Germany).

\subsubsection{Alkaline phosphatase activity and calcium quantification}

After 21 days, cells were washed with PBS and lysated with $0.1 \%$ Triton X-100. Alkaline phosphatase (ALP) activity was quantified by measuring the cleavage of p-nitrophenyl phosphate (pNPP, Sigma-Aldrich) in a soluble yellow end-product that absorbs at $405 \mathrm{~nm}$. Twenty-five microliters of sample were incubated with $100 \mu \mathrm{l}$ pPP. In parallel to the samples, a standard curve with calf intestinal ALP (Promega, Madison, WI, USA) was constructed. For calcium quantification, $200 \mu \mathrm{l}$ of sample were incubated with $1 \mathrm{M} \mathrm{HCl}$ overnight, followed by centrifugation at $500 \times \mathrm{g}$ for 2 min for the subsequent determination of calcium content in the supernatant with an atomic absorption spectrometer (AAnalyst 400, PerkinElmer, Waltham, MA, USA). Data were compared with $\mathrm{CaCl}_{2}$ standards included in the assay.

\subsection{Bacteria assays}




\subsubsection{Bacteria culture}

Bioluminescent Staphylococcus epidermidis Xen43 and Staphylococcus aureus Xen29 were cultured in tryptone soya broth (TSB; CM0129, Oxoid, Basingstoke, UK) at $37^{\circ} \mathrm{C}$ in aerobic atmosphere. When optical density $\left(\mathrm{OD}_{600}\right)$ reached $0.4-0.5$, the bacteria were diluted 1:100 in TSB and incubated overnight. For all bacterial experiments, sample discs were inoculated with the overnight bacteria suspension diluted 1:100 in $\mathrm{TSB}\left(\mathrm{OD}_{600}=0.04-0.05\right.$, corresponding to approximately $\left.1 \times 10^{7} \mathrm{CFUs} / \mathrm{ml}\right)$. Each experiment was repeated four times with three sample discs per group $(n=12)$ unless otherwise stated.

\subsubsection{Biofilm formation}

Sample discs were placed in 96-well opaque microplates (OptiPlate-96, PerkinElmer) and inoculated with $150 \mu \mathrm{l}$ of bacteria suspension. The well plates were sealed with transparent adhesive seals (TopSeal ${ }^{\mathrm{TM}}$ A-Plus, PerkinElmer) and incubated at $37^{\circ} \mathrm{C}$ in a multi-detection plate reader (Synergy HT, BioTek, Winooski, VT, USA). This setup will hereafter be referred to as the "biofilm setup". Luminescence was measured from the top following $10 \mathrm{~s}$ shaking of the plate every $15 \mathrm{~min}$ for $12 \mathrm{~h}$, after which the optical density of the planktonic bacteria collected from the wells was measured. One sample disc per group was removed from the well and gently rinsed with PBS to remove non-adherent bacteria from the sample surface. Each disc was then placed in a sterile Eppendorf tube containing $500 \mu 1$ PBS and bath sonicated at $37 \mathrm{kHz}$ with power output of $290 \mathrm{~W}$ at $37^{\circ} \mathrm{C}$ for $3 \mathrm{~min}$ to detach the adherent biofilm from the sample surface. After sonication, three $15 \mu \mathrm{l}$ droplets of detached bacteria serially diluted in PBS were cultured on tryptone soya agar (TSA) plates. The number of colony-forming units (CFUs) was counted after $24 \mathrm{~h}$ incubation at $37^{\circ} \mathrm{C}$. 


\subsubsection{Effect of released phenolic compounds}

To investigate the effect of phenolic compounds released from the coated surfaces on bacterial viability and growth, biofilm formation on the sample surface was minimised by reducing sedimentation and adhesion of planktonic bacteria onto the surface of the sample discs. For this purpose, threaded stainless steel pins were fitted through customised 96-well microplate lid segments and sample discs with threaded holes were fixed onto pins with the mirror-polished surface facing down (Figure S1, supporting information). This setup will hereafter be referred to as the "release setup". Opaque optical-bottom 96-well microplates (Nunc ${ }^{\mathrm{TM}}$, Thermo Scientific) were inoculated with $100 \mu \mathrm{l}$ of bacteria suspension and the sample discs were mounted into the wells to expose the polished surface to the bacteria suspension. The well plates were sealed with parafilm and incubated at $37^{\circ} \mathrm{C}$ in a multi-detection plate reader (Synergy HT, BioTek). Luminescence was measured following $10 \mathrm{~s}$ shaking of the plate every $15 \mathrm{~min}$ for up to $12 \mathrm{~h}$. Lid segments containing the sample discs were removed after 2, 6, and 12 hour incubation and the sample discs were immediately rinsed with PBS to remove nonadherent bacteria from the sample surface. Optical density of the planktonic bacteria collected from the wells following the removal of the sample discs was measured and the bacteria were cultured on TSA plates after being serially diluted in PBS to obtain appropriate CFU density. The number of CFUs was counted after $24 \mathrm{~h}$ incubation at $37^{\circ} \mathrm{C}$. Furthermore, the rinsed coins removed from the lid segments after 2 and $6 \mathrm{~h}$ incubation were placed in opaque 96-well microplates with the mirror-polished side facing up and reincubated in $150 \mu 1$ of fresh TSB to assess the viability of the adherent bacteria. The well plates were sealed with transparent adhesive seals and incubated at $37^{\circ} \mathrm{C}$ in a multi-detection plate reader (Cytation 3, BioTek). Luminescence was measured following $10 \mathrm{~s}$ shaking of the plate every $15 \mathrm{~min}$ for $12 \mathrm{~h}$. In addition, both planktonic bacterial growth and biofilm formation in the presence of dissolved and oxidised tannic acid and pyrogallol molecules were assessed as detailed in the supporting 
information to compare the effect of the released molecules to known concentration of the precursor molecules.

\subsubsection{Imaging with confocal and scanning electron microscopy}

Sample discs $(n=4)$ were placed in 48 -well cell culture plate and inoculated with $700 \mu 1$ of the overnight bacteria suspension diluted $1: 100$ in TSB $\left(\mathrm{OD}_{600}=0.04-0.05\right)$ and incubated at $37^{\circ} \mathrm{C}$ for 2,6 , or $12 \mathrm{~h}$.

For confocal laser scanning microscopy, bacteria on the sample surfaces were stained for bacterial viability (LIVE/DEAD ${ }^{\circledR}$ BacLight $^{\mathrm{TM}}$, Molecular Probes, Eugene, USA) according to the manufacturer's protocol. The samples were imaged at three non-overlapping areas immediately after staining using a Leica SP8 upright CLSM with 40× objective using $488 \mathrm{~nm}$ and $552 \mathrm{~nm}$ excitation wavelengths for SYTO9 (live) and propidium iodine (dead) stains, respectively.

For SEM imaging, bacteria on the sample surfaces were fixed with $2.5 \%$ glutaraldehyde in 0.1 M Sørensen phosphate buffer. The samples were then rinsed with PBS, dehydrated with a graded ethanol series $(50 \%, 75 \%, 90 \%, 100 \%)$, sputtered with gold/palladium and examined by SEM (TM-3030, Hitachi, Tokyo, Japan). Additional colour overlaying on SEM micrographs was performed with Adobe Photoshop CS6 to highlight the adhered bacteria on the Ti surfaces.

\subsection{Statistical analyses}

The Shapiro-Wilk test was performed to test for parametric or non-parametric distribution. Differences between groups were assessed by unpaired $t$-test or Mann-Whitney rank sum test, depending on data distribution. Results were considered statistically significant at $p<0.05$. All statistical analyses were performed using SigmaPlot 13 (Systat Software Inc., Chicago, IL, USA). Error bars have been omitted from the datapoints presented for measured luminescence values to improve legibility of the graphs. 


\section{Results}

\subsection{Stability of the phenolic coatings}

Coating stability was examined by rinsing TA and PG coatings with PBS at raised temperature of $37^{\circ} \mathrm{C}$ for $12 \mathrm{~h}$ while monitoring the frequency shifts of the titanium coated quartz crystal (Figure 1). PBS rinsing resulted in a positive frequency shift for TA2, TA24, and PG24 with TA2 showing the largest frequency variation. Only PG2 showed slightly more negative frequency values after rinsing. Quantitative analysis of the frequency shifts is presented in Table 1. As expected, the dissipation was also affected by rinsing with PBS and a negative shift was produced for all the coatings (Figure S2). Altogether, these measurements indicate that exposing the deposited coating to constant flow of PBS at $37^{\circ} \mathrm{C}$ provokes release of phenolic molecules from the surface of the coating, yielding a thinner coating layer after the $12 \mathrm{~h}$ rinsing.

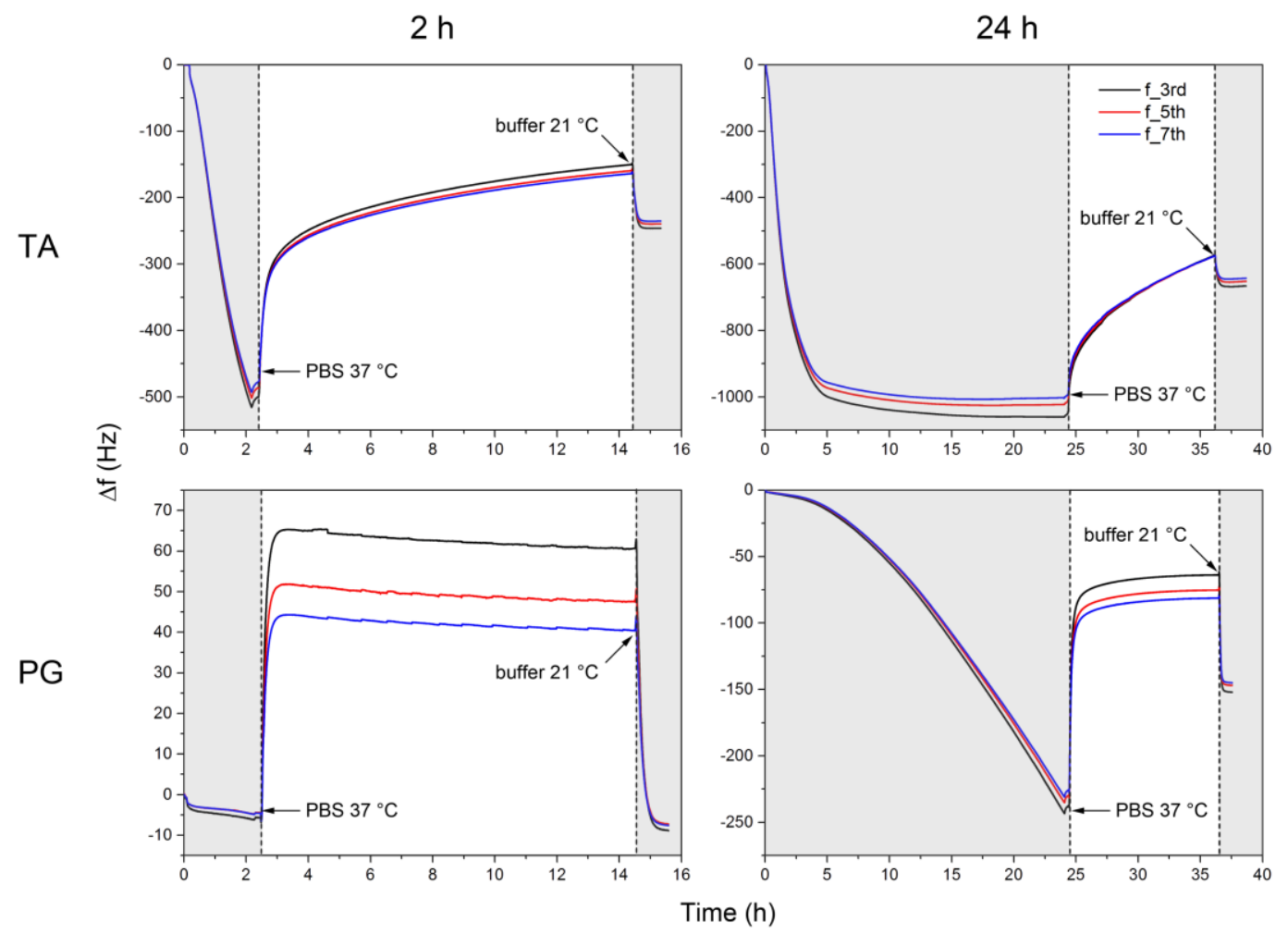

Figure 1. Representative frequency shifts of the third, fifth, and seventh harmonic for TA and PG coating deposition. After coating times of $2 \mathrm{~h}$ (thin coating, left panel) and $24 \mathrm{~h}$ (thick coating, right panel), the quartz crystals were first rinsed with coating buffer, followed by a 
$12 \mathrm{~h}$ rinse with $\mathrm{PBS}$ at $37^{\circ} \mathrm{C}$ (white background). After this, the crystals were again rinsed with coating buffer at $21^{\circ} \mathrm{C}$. Figure S3 illustrates the influence of the temperature change and the difference in buffer composition on the frequency signal in more detail.

Table 1. Frequency difference before and after the PBS rinse in the fifth harmonic (mean $\pm S D$, $n=4)$.

\begin{tabular}{ccc}
\hline & fraction $(\%)$ & absolute $(\mathbf{H z})$ \\
\hline TA2 & $47.6 \pm 1.8$ & $286.0 \pm 65.5$ \\
TA24 & $39.4 \pm 3.4$ & $364.4 \pm 64.4$ \\
PG2 & $-20.5 \pm 37.8$ & $-1.9 \pm 1.4$ \\
PG24 & $37.7 \pm 9.8$ & $106.8 \pm 50.4$ \\
\hline
\end{tabular}

\subsection{Cell study}

\subsubsection{Cytotoxicity of modified surfaces and cell morphology}

The cytotoxicity of both TA coated surfaces on hOBs was increased after 2 days of cell culture compared to the unmodified titanium control surfaces (Figure 2). While PG24 did not exhibit significantly different cytotoxicity compared to control, PG2 coatings showed lower cytotoxicity compared to PG24 and control. Staining of cytoskeleton and nuclei revealed good cell spreading and normal cell morphology of hOBs on all tested surfaces (Figure 2). The metabolic activity of hOBs on the modified surfaces was measured after 2 days of cell culture as an index of cell viability (Figure $\mathrm{S} 4$, supporting information). No significant difference in metabolic activity compared to the control surfaces could be detected. 

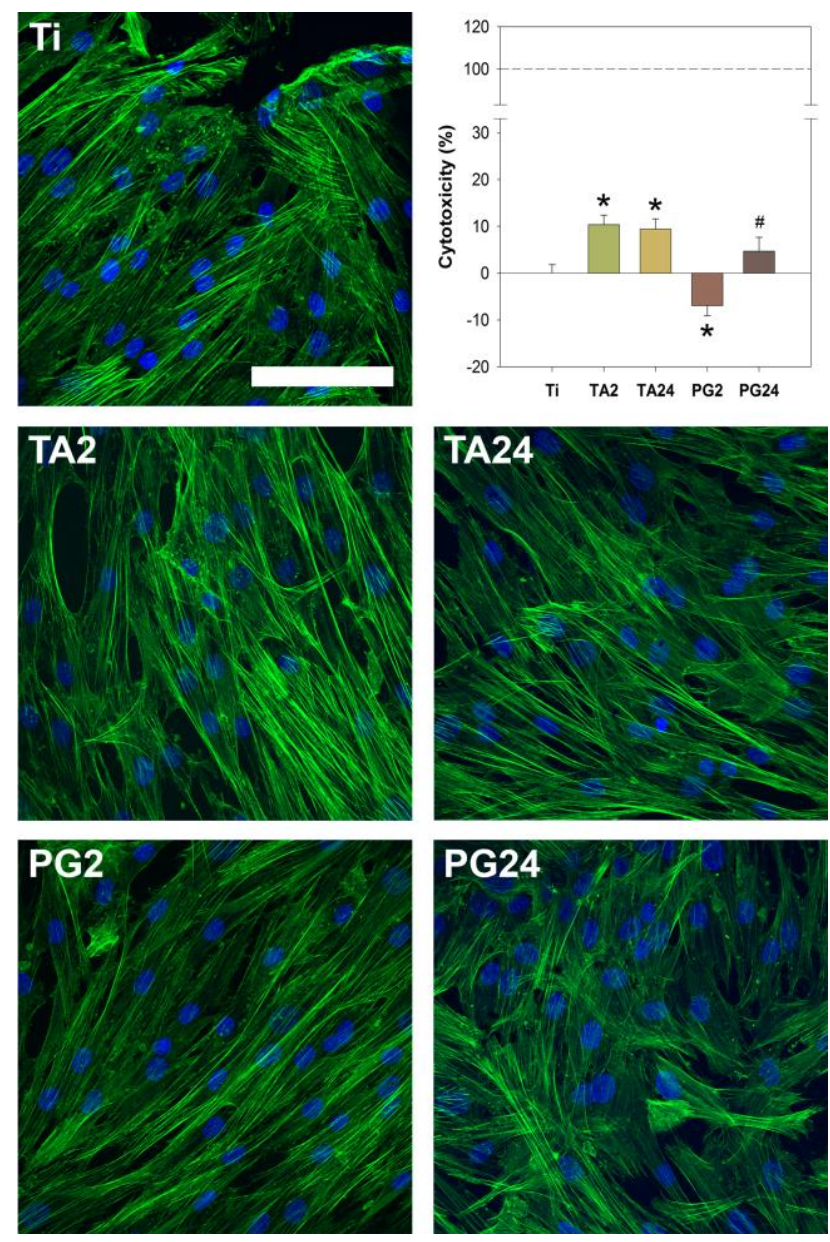

Figure 2. Cell morphology of hOBs after 2 days of cell culture (blue: nuclei; green: cytoskeleton; scale bar $100 \mu \mathrm{m}$ ) and cytotoxicity of the polyphenol coated surfaces (mean $\pm \mathrm{SEM}, n=6,{ }^{*} p<0.05 v s \mathrm{Ti}, \# p<0.0524 \mathrm{~h} v s 2 \mathrm{~h}$ coatings). 

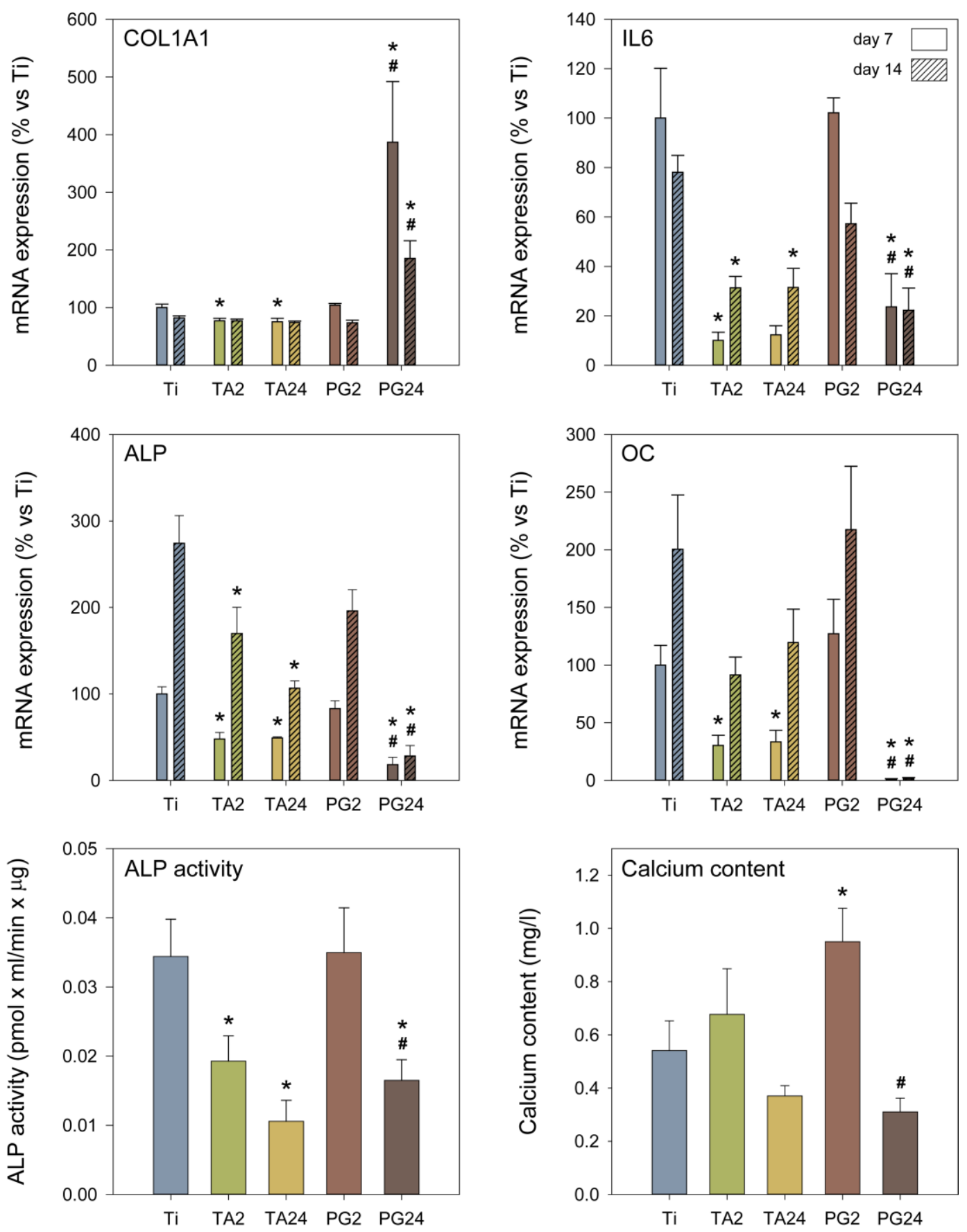

Figure 3. Gene expression of collagen (COL1A1), interleukin-6 (IL6), alkaline phosphatase (ALP), and osteocalcin (OC) after 7 and 14 days of hOB culture. ALP activity normalised by total protein and calcium content of the hOBs after 21 days of culture (mean $\pm \mathrm{SEM}, n=6,{ }^{*} p<0.05 v s \mathrm{Ti}, \# p<0.05$ $24 \mathrm{~h} v s 2 \mathrm{~h}$ coatings).

\subsubsection{Gene expression analysis}

The expression of genes related to osteoblast growth, matrix maturation, and mineralisation was assessed after 7 and 14 days of hOB culture on the polyphenol coated surfaces (Figure 3). 
COL1A1 mRNA levels were significantly increased on PG24 coatings after both time points when compared to control surfaces and PG2 coatings, and decreased on both TA coated surfaces compared to control after 7 days. The mRNA levels of both IL6 and ALP were decreased on TA coated surfaces and on PG24 coatings compared to control for both time points. OC mRNA expression was decreased for TA coated surfaces after 7 days, and for PG24 coatings after 7 and 14 days of cell culture compared to the control surfaces. ALP activity measured after 21 days was decreased for both TA coated surfaces and PG24 coatings. The calcium content after 21 days was significantly increased for PG2 coatings compared to control and PG24.

\subsection{Bacterial assay}

\subsubsection{Biofilm formation}

After $12 \mathrm{~h}$, the optical density of the bacteria collected from the wells was significantly reduced for TA24 and PG24 when compared to the control group and to the $2 \mathrm{~h}$ coatings in both $S$. epidermidis and S. aureus cultures (Figure 4). Similarly, the number of colony-forming units from the detached biofilm after $12 \mathrm{~h}$ incubation revealed no significant differences among the groups for either staphylococcal species. For S. epidermidis Xen43, no clear difference was observed in the measured luminescence between the sample groups apart from the PG24 coatings, which exhibited lower luminescence values compared to the other groups during the entire $12 \mathrm{~h}$ incubation time (Figure S5). However, the luminescence curves for S. aureus Xen29 showed a marked decrease in the peak luminescence values for all coated samples with increasing coating thickness resulting in reduced luminescence. Furthermore, lower luminescence values were observed for PG than for TA with similar coating times (Figure S6). 

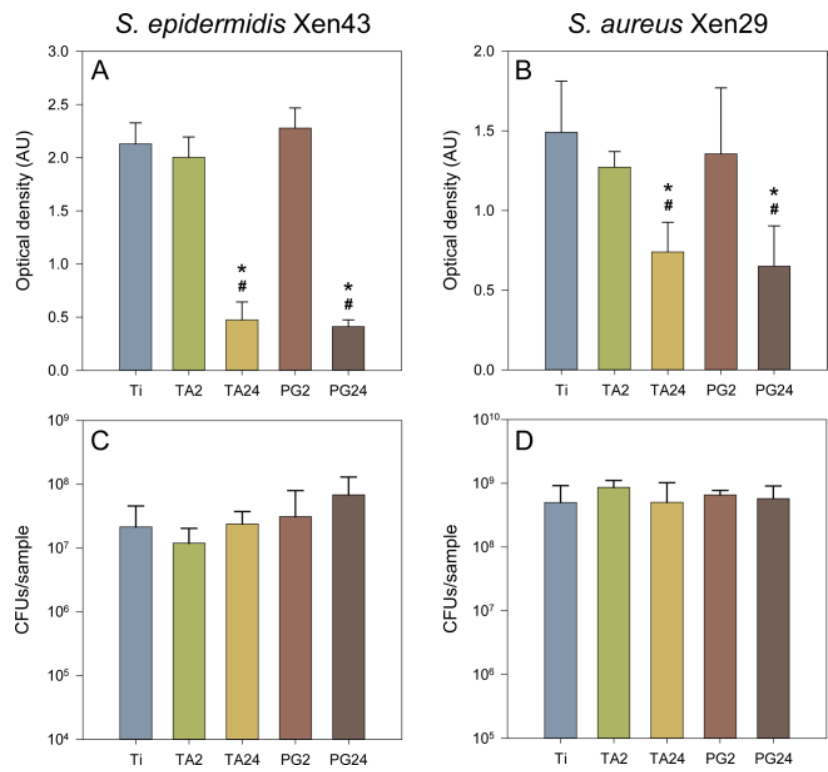

Figure 4. (A \& B) Optical density of the planktonic bacteria collected from the wells in the biofilm setup after 12 h. (C \& D) Number of colony-forming units (CFUs) in the biofilm formed on the discs after $12 \mathrm{~h}$ (mean of means $\pm \mathrm{SD}, n=4 \times 3,{ }^{*} p<0.05 v s \mathrm{Ti}, \# p<0.0524 \mathrm{~h} v s 2 \mathrm{~h}$ coatings).

SEM imaging of the disc surfaces after $2 \mathrm{~h}$ of bacteria incubation showed comparable bacterial colonisation on all surfaces inoculated with S. epidermidis (Figure 5). However, live/dead staining at this time point revealed that while mostly live bacteria were present on the control surface and on TA2, the major part of bacteria on the other surfaces were stained dead. Considerably more viable bacteria were observed for PG2 compared to PG24, which showed only few viable bacteria. After 6 and $12 \mathrm{~h}$ of incubation, distinct biofilm formation was observed on all surfaces (Figure 5, Figure S7) with predominantly viable bacteria as determined by live/dead staining. Similar findings were also observed for the $S$. aureus biofilm formation, although the amount of bacteria adhering to the sample surfaces was considerably lower in comparison to $S$. epidermidis, particularly for the TA24 and PG24 samples incubated for only $2 \mathrm{~h}$ (Figure S8). 


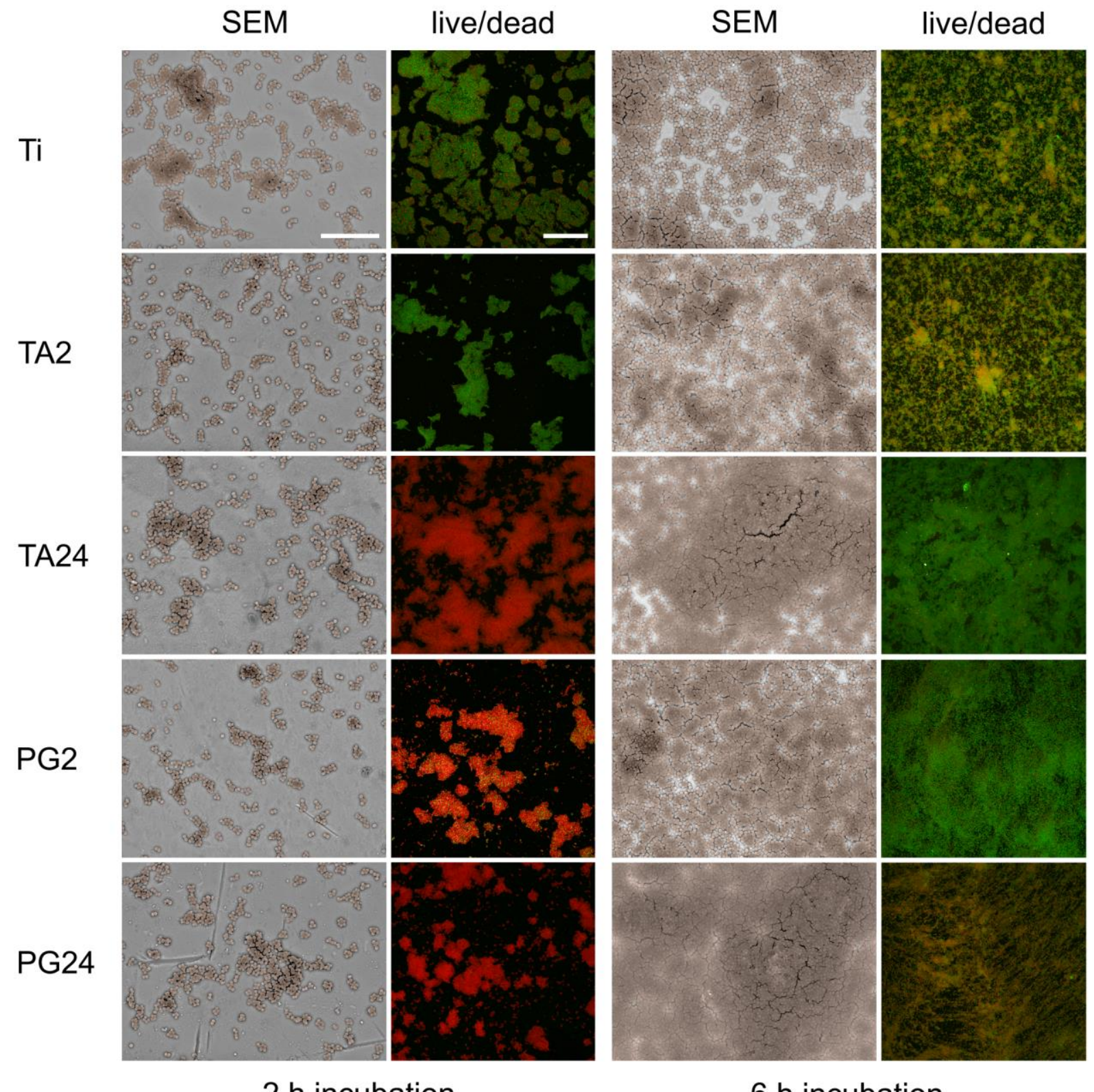

$2 \mathrm{~h}$ incubation

$6 \mathrm{~h}$ incubation

Figure 5. SEM images of the different sample surfaces after 2 and $6 \mathrm{~h}$ of $S$. epidermidis incubation in the biofilm setup (scale bar $15 \mu \mathrm{m}$ ) and corresponding live/dead staining (green: living bacteria; red: dead bacteria; scale bar $60 \mu \mathrm{m})$.

\subsubsection{Effect of release of phenolic compounds}

Optical density measurements and detected colony-forming units from the planktonic bacteria collected from the wells after 2, 6, and $12 \mathrm{~h}$ are depicted in Figure 6. While there was no statistical difference in the OD of the different groups compared to the control group after $2 \mathrm{~h}$, OD was lowest for TA24 and significantly less CFUs were counted for this group. After $6 \mathrm{~h}$ of 
incubation, both TA groups and PG24 revealed less OD, and there was a clear reduction in CFUs for TA24 and PG24. After $12 \mathrm{~h}$, all groups exhibited decreased OD compared to the control group, and fewest CFUs were counted for TA24 and PG24. Similar to the biofilm setup, lower luminescence values were measured for PG24 over the entire incubation time, while no difference was observed in the behaviour of the rest of the tested groups in comparison to bacteria cultures on Ti surfaces (Figure S9).
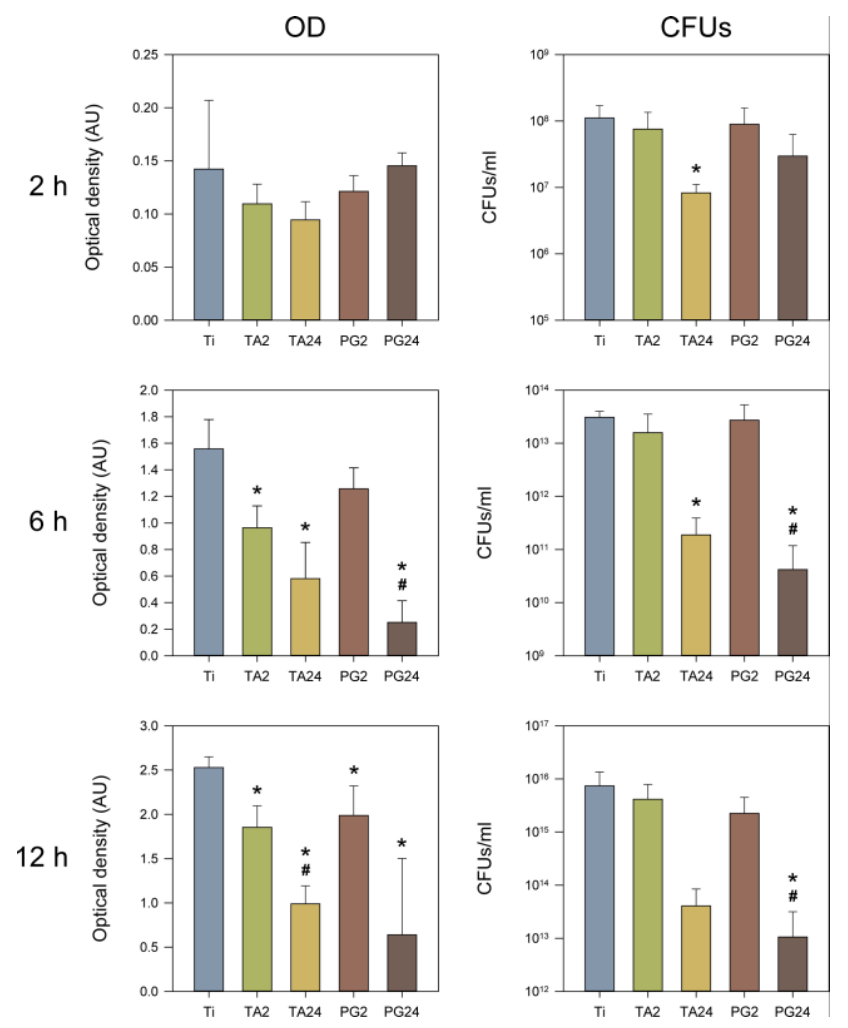

Figure 6. Optical density (OD) and number of colony-forming units (CFUs) of the planktonic bacteria collected from the wells in the release setup after 2,6 , and $12 \mathrm{~h}$ (mean of means $\pm \mathrm{SD}, n=4 \times 3$, ${ }^{*} p<0.05$ vs Ti, \#p $<0.0524$ h vs 2 h coatings).

Growth of viable bacteria that had adhered onto the sample surfaces during the initial 2 and $6 \mathrm{~h}$ incubation period is shown in Figure 7. Despite the slight delay in start of the exponential increase in luminescence observed for both PG groups after $2 \mathrm{~h}$ initial incubation, no statistically significant difference was found in the time needed to reach the half maximum luminescence value $\left(t_{\mathrm{max} / 2}\right)$ during reincubation in fresh TSB for any of the tested samples. 

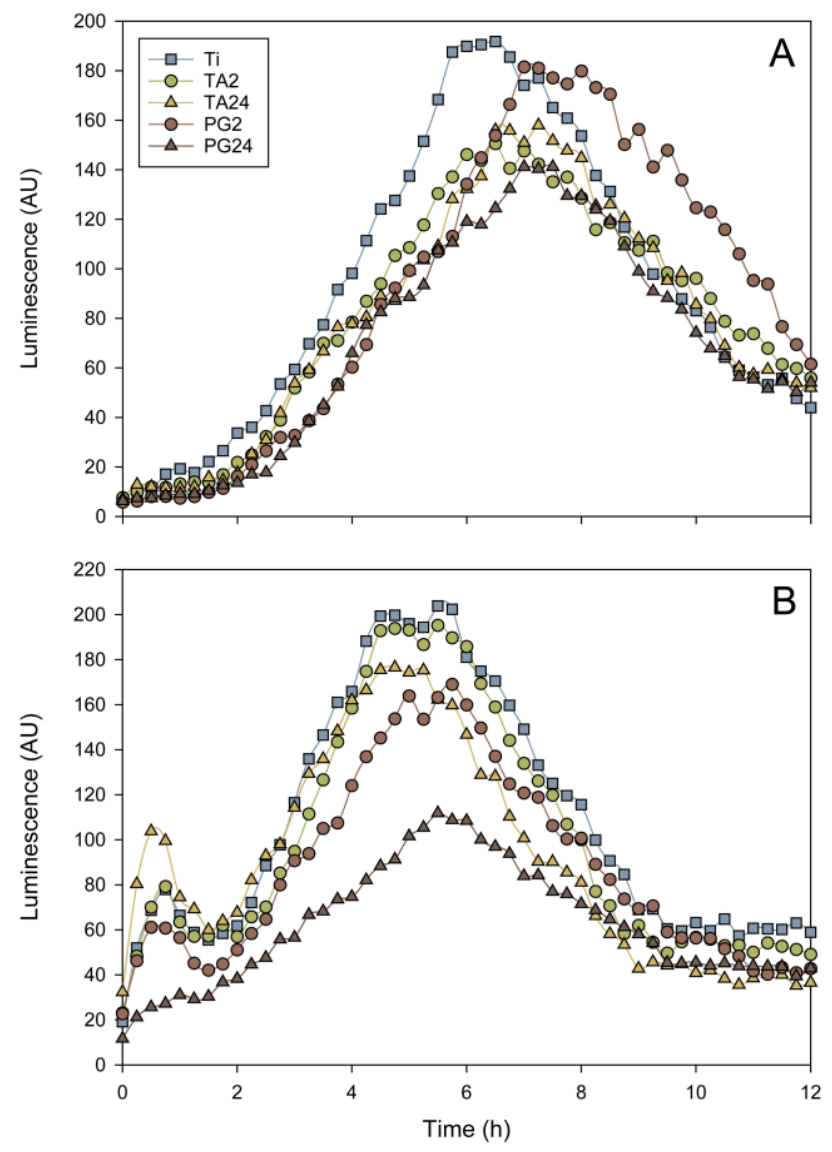

Figure 7. Luminescence measured during reincubation of sample discs removed from the release setup after (A) $2 \mathrm{~h}$ incubation and (B) $6 \mathrm{~h}$ incubation (mean, $\mathrm{n}=12$ ). The discs were rinsed with PBS to remove non-adherent bacteria from the sample surfaces prior to reincubation in fresh TSB. $\bullet 2 \mathrm{~h}$ coatings, $\Delta 24$ h coatings, $\mathbf{\square}$ uncoated Ti surface

Supporting information further details the results from the exposure of the bacteria to known concentration of the dissolved and oxidised polyphenolic compounds (Figures S10-S14). In short, a clear concentration dependent reduction in CFUs was seen after $6 \mathrm{~h}$ in all tested staphylococcal strains (Figure S10), with the oxidised molecules being more efficient in inhibiting the growth of planktonic bacteria than the precursor molecules (Figure S11). However, reduction in biofilm formation was only observed for concentrations that were found to inhibit growth of the bacteria (Figure S12). Interestingly, the presence of the phenolic compounds appeared to rather stimulate than inhibit both S. epidermidis and S. aureus biofilm formation. 


\section{Discussion}

Auto-oxidative surface polymerisation of phenolic compounds represents a simple and versatile functionalisation method for a broad range of different materials, including titanium. ${ }^{24-25}$ The aim of the present study was to investigate the potential application of such surface coatings made from tannic acid and pyrogallol to create multifunctional surfaces for endosseous titanium implants, which can promote the bone tissue response and reduce the risk of implant-associated infections. Therefore, the in vitro performance of TA and PG coated titanium discs was assessed using cultures of both primary human osteoblasts and biofilmforming S. epidermidis. In a previous study, we demonstrated that the structure and thickness of TA and PG coatings is dependent on the duration of the coating process ${ }^{28}$ For this reason, the biological effect was tested for coatings deposited for two different coating times, $2 \mathrm{~h}$ and $24 \mathrm{~h}$, resulting in coatings thicknesses of approximately $10-30 \mathrm{~nm}$ and $60-80 \mathrm{~nm}$, respectively. ${ }^{28}$

\subsection{Effect of modified surfaces on human osteoblasts}

Since osteoblasts are the cells involved in bone formation by synthesising and depositing the bone extracellular matrix, ${ }^{30}$ this study employed primary human osteoblasts in order to investigate the effect of TA and PG coatings on bone tissue. Despite the significant differences observed in cytotoxicity, the variation between the test groups was low and none of the samples showed high LDH activity, which could be considered a sign of cytotoxic effect of the coatings or released phenolic molecules on hOBs. Biocompatibility of the coatings was confirmed by means of cell imaging, revealing a healthy spindle-shaped morphology of the cells on all modified surfaces. Moreover, the metabolic activity of the cells was not influenced in presence of the coatings, and was similar to that on the titanium control surface. This is in accordance with the findings by Sileika et al., who demonstrated that similar surface coatings made from TA and PG were non-toxic to fibroblastic cells. ${ }^{25}$ 
Osteoblast maturation is characterised by a sequential upregulation of genes related to proliferation, extracellular matrix maturation, and mineralisation. ${ }^{31}$ After an initial increased deposition of collagen, ALP is highly expressed during the matrix maturation phase, followed by increased expression of OC during the mineralisation phase. ${ }^{31}$ On the basis of these three osteoblast markers, the results obtained in the present study indicate that PG24 coatings delayed the maturation of hOBs. The significantly increased expression of COL1A1, while both ALP and OC expression remained significantly lower compared to the control surfaces for both analysed time points, are a sign that the cells on PG24 coatings were still in the proliferation phase where mainly collagen deposition takes place. Similarly, but to a less extent, the decreased ALP expression and activity point to a delayed maturation of the cells on TA coatings.

In contrast, PG2 coatings seemed to have a positive effect on the maturation of hOBs. Although the gene expression profiles were not significantly different compared to the control surfaces, hOBs exhibited highest $\mathrm{OC}$ expression on these surfaces at both time points. The gene expression of the mineralisation marker OC has been reported to be one of the main predictive markers of osseointegration in vivo. ${ }^{32}$ Together with the significantly increased calcium content in the extracellular matrix of the hOBs, which is the hallmark of bone tissue, this indicates that the maturation of osteoblasts was promoted in the presence of PG2 surfaces. However, the use of only one donor of osteoblasts represents a limitation of the present study, and further experiments should be conducted to confirm these results.

Apart from PG2, all of the polyphenol modified surfaces induced downregulation of IL6 gene expression. The multifunctional cytokine IL-6 is produced by a variety of cells and plays a role in the regulation of the immune response and inflammatory reactions. ${ }^{33}$ It is also involved in bone repair by regulating the differentiation of both osteoblasts and osteoclasts, and by promoting angiogenesis. ${ }^{34-35}$ Absence of IL-6 has been shown to delay mineralisation and 
remodelling of the fracture callus in the early stages of bone fracture healing. ${ }^{34,36}$ On the other hand, increased IL-6 levels have been related to pathological inflammatory conditions associated with chronic diseases ${ }^{37}$ For example, tissue degeneration during periodontal disease has been connected to elevated levels of IL-6 and its promotion of bone resorption. ${ }^{38-43}$ Similar situations are also found in other clinical scenarios linked to local inflammation and bone destruction, for instance in rheumatoid arthritis and osteoporosis. ${ }^{37,}{ }^{44-45}$ The observed downregulation of the IL6 gene could therefore be an indication of the anti-inflammatory potential of the polyphenol coated surfaces. In fact, decreased IL6 gene expression has recently been observed for human gingival fibroblasts cultured on titanium surfaces with covalently bound polyphenols, an effect that has been attributed to the anti-inflammatory properties of such polyphenol modified surfaces ${ }^{46}$ Considering the involvement of inflammatory signals in bone regeneration and their influence on tissue destruction in pathological situations, functionalised implant surfaces that can contribute to the regulation of inflammation could be a promising way to influence the interaction between the host tissue and the implant, particularly in the medically compromised patient. ${ }^{36}$ Future investigations on the effect of the coatings on inflammatory processes should be performed using an in vitro inflammation model. The results obtained in this study indicate a correlation between the biological performance of the surfaces and the structural properties and integrity of the phenolic coatings. As demonstrated in our previous study, the coating buildup for the PG system was very slow in the beginning, resulting in a coating thickness of less than $10 \mathrm{~nm}$ after $2 \mathrm{~h}$ of coating time, while the coatings were much thicker after a coating time of $24 \mathrm{~h}$, with a thickness of approximately $75 \mathrm{~nm} \cdot{ }^{28}$ In comparison to that, TA coatings revealed a rapid initial increase in thickness with a compact and rigid coating structure up to $2 \mathrm{~h}$ of coating time, after which the coating became softer and the thickness levelled at approximately $50-60 \mathrm{~nm} .{ }^{28}$ Hypothesising that these differences in coating structure and thickness, and therefore also in the amount of 
phenolic compounds on the surfaces, might have an influence on the potential release of phenolic compounds from the surfaces, we tested the release by means of a quartz crystal microbalance. Increase in frequency and concurrent reduction in dissipation after the rinsing step was correlated to a decrease in mass on the crystal surface, and was therefore used as an indicator of release of phenolic compounds from the surface (Figures 1 and S2). However, since TA and PG coatings have been shown to exhibit viscoelastic properties, especially for long coating times, ${ }^{28}$ the frequency changes were only used as a qualitative measure of mass release from the surface, as frequency changes for viscoelastic layers can also involve structural changes and release of coupled water from the surface. ${ }^{47}$ Furthermore, constant flow of proteinfree PBS does not fully represent the liquid environment of the static cell culture experiments, and the release of the phenolic compounds from the coated surfaces is expected to occur slower in both the static cell culture environment in vitro as well as in the more complex physiological environment in vivo. While both TA coated surfaces and PG24 showed an increase in frequency after he PBS rinse, the frequency changed only very little for PG2 coatings (Figure 1). Therefore, both TA2 and TA24 coatings exhibited mass release from the surface, and this may explain the observed similar effects of these groups on osteoblasts. In contrast, for all analysed genes, the expression was significantly different between PG2 and PG24. The same phenomenon was observed for ALP activity and the calcium content after 21 days of cell culture. This different biological effect of the PG coatings may arise from the different release behaviour of PG2 and PG24, with PG24 releasing phenolic compounds from the surface, which was not observed for PG2 surfaces.

Despite the frequently reported antioxidant activity of polyphenols, some phenolic compounds, including pyrogallol, have also been reported to act as pro-oxidants and to produce significant amounts of hydrogen peroxide $\left(\mathrm{H}_{2} \mathrm{O}_{2}\right)$ under quasi-physiological conditions. ${ }^{48} \mathrm{H}_{2} \mathrm{O}_{2}$ is involved in signal transduction pathways, it has an effect on the activity of enzymes and 
transcription factors, and can influence gene expression and cause DNA damage. ${ }^{49}$ Therefore, the observed delay in osteoblast maturation might be the result of an oxidative stress reaction of the cells related to $\mathrm{H}_{2} \mathrm{O}_{2}$ production, in particular for PG24 coatings. ${ }^{50-51}$ While this theory would conflict with the previously reported antioxidant properties of TA coatings, PG coatings have been found to be less effective in their antioxidant properties. ${ }^{25}$

\subsection{Effect of modified surfaces on staphylococcal biofilm formation}

In addition to their anti-inflammatory and osteopromotive potential, polyphenols are wellknown for their inherent antimicrobial nature, ${ }^{52-55}$ and thus, polyphenols have recently attracted increasing interest as surface functionalisation strategies for biofilm-resistant medical implant materials. ${ }^{25,}$ 56-59 Tannic acid in particular has been reported to inhibit biofilm formation of several different bacterial species, while not affecting the planktonic growth of these bacteria. ${ }^{60-65}$ Payne et al., for example, found that tannic acid was able to prevent $S$. aureus biofilm formation via inducing high expression of immunodominant staphylococcal antigen A (IsaA), likely resulting in cleavage of the polysaccharide backbone of the peptidoglycan layer in the cell wall, and thus, preventing surface colonisation. ${ }^{63}$ Although S. epidermidis has also been shown to secrete the lytic transglycosylase IsaA, ${ }^{66}$ no inhibitory effect on either $S$. epidermidis or S. aureus biofilm formation was observed when the bacteria were cultured on the TA- and PG-coated titanium surfaces in the present study.

However, unlike the previous studies in which the effect of tannic acid was evaluated by adding the molecules in suspension to the bacterial culture, the phenolic compounds in our study were deposited on the surfaces of the analysed substrates. During the auto-oxidative surface deposition, the phenolic molecules react with each other and form a thin polymer layer on the Ti discs. ${ }^{28}$ Since the exact composition of these phenolic layers is not clear, the structure of the released compounds might be different from the pure precursor molecules, and therefore, also exhibit different interaction mechanisms with the bacterial cells. Nevertheless, both TA and 
PG failed to elicit inhibitory effect on both S. epidermidis and S. aureus biofilm formation also when exposed to subinhibitory concentrations ([TA/PG] $<100 \mu \mathrm{g} / \mathrm{ml}$ ) of either non-oxidised or oxidised precursor molecules in solution phase as detailed in the supporting information (Figures S10-S11). Instead, biofilm formation appeared to be somewhat stimulated even for concentrations that reduced planktonic growth (Figure S12), particularly for the oxidised precursor molecules and the polymerised particles mimicking the properties of the phenolic coatings (Figure S13). Morán et al. have previously reported similar stimulatory effect on $S$. epidermidis biofilm formation when the bacteria were exposed to several phenolic acids at subinhibitory concentrations, while the same concentration of the tested phenolic acids had almost no effect on S. aureus biofilm formation. ${ }^{67}$ Similar inefficiency of polyphenolic compounds to prevent $S$. epidermidis biofilm formation has further been observed in the presence of pentagalloyl glucose (PGG), ${ }^{62}$ a polyphenolic component often found in commercial tannic acid that has been shown to significantly inhibit $S$. aureus biofilm formation at concentrations below $20 \mu \mathrm{M}$ (corresponding to $34 \mu \mathrm{g} / \mathrm{ml} \mathrm{TA}$ ). ${ }^{62,}{ }^{68}$ Such resistance to the biofilm-inhibiting effect of TA has also been reported for several S. aureus strains. Payne et $a l$., for example, found that some of their $S$. aureus isolates formed a robust biofilm in the presence of TA and related this to their failure to produce IsaA and the overproduction of polysaccharide intracellular adhesin (PIA). ${ }^{63,68}$ The observed lack of the antibiofilm activity of TA and PG for both S. aureus and S. epidermidis may therefore stem from difference in the biofilm-forming capacity of different staphylococcal strains, as also suggested by Dong et al., who observed large variations in the TA-induced biofilm inhibition among several methicillinresistant S. aureus isolates. ${ }^{69}$ However, the dose-dependent reduction in bioluminescence observed for S. aureus Xen29 in the biofilm setup (Figure S6) indicates that the two different staphylococcal species seem to respond differently when cultured on the polyphenolic coated 
surfaces, with $S$. aureus Xen29 being more susceptible to the antibacterial effect of TA and PG as similar reduction in luminescence was not observed for S. epidermidis Xen43 (Figure S5). While the polyphenolic coatings were not found to inhibit the surface colonisation and biofilm formation of either S. epidermidis or S. aureus, release of phenolic compounds particularly from the thicker polyphenolic coatings (TA24 and PG24) resulted in significant reduction in growth of planktonic bacteria in both tested setups (Figures 4 and 6). This is consistent with the study by Taguri et al., who reported that TA exhibited moderate antibacterial activity against Gram-positive bacteria, whereas PG had strong antibacterial activity against all tested bacteria strains. ${ }^{55}$ Several theories exist for the mechanisms behind the antibacterial activity of polyphenols. As already mentioned earlier with respect to the effect of the phenolic coatings on osteoblast cells, polyphenols and PG in particular can produce a significant amount of hydrogen peroxide. ${ }^{48}$ This $\mathrm{H}_{2} \mathrm{O}_{2}$ formation has been correlated to the antibacterial activity of phenolic compounds. ${ }^{70}$ Moreover, Scalbert reported that the antimicrobial activity of tannins might be related to three mechanisms: the complexation of enzymes or substrates, interaction with the membranes of microorganisms, or complexation and deprivation of metal ions. ${ }^{52}$ Interestingly, studies have also shown that flavonoids can cause aggregation of whole bacterial cells, ${ }^{71-72}$ resulting in possible misinterpretation of reduced numbers of CFUs as the whole bacterial aggregate is counted as one CFU. ${ }^{53}$ Such aggregation and subsequent recruitment of viable and metabolically active bacterial cells to a biofilm could provide an alternative explanation for the observed dose-dependent reduction in both OD and number of CFUs in the sample wells, particularly in the absence of a clear change in the luminescence values between the groups for S. epidermidis (Figures S5).

Surprisingly, a significant number of the bacteria colonising the surfaces of TA24 coatings and both PG coatings were stained dead when performing live/dead staining after 2 h (Figures 6 and S8). While this finding is in good agreement with previously reported contact-killing 
properties of TA and PG coatings ${ }^{25}$ and permanent damage to the peptidoglycan layer of $S$. aureus cell wall upon exposure to polyphenolic compound epigallocatechin gallate, ${ }^{73}$ the absence of significant delay in the measured luminescence observed in Figure 7A indicated no difference in the viability of the adherent bacteria after $2 \mathrm{~h}$ direct exposure to the TA and PG coatings. As the luminescence has previously been shown to linearly correlate with growth of viable bacteria until the maximum luminescence is reached in a similar experimental setup, ${ }^{74}$ a more pronounced delay in luminescence would be expected had the direct contact with the polyphenol coatings resulted in excessive cell death as indicated by the live/dead staining. This implies that the live/dead staining alone may yield a false impression on the viability of the early colonising bacteria observed on especially the thicker TA24 and PG24 coatings, particularly in light of the large number of viable bacteria that were observed on the sample surfaces following live/dead staining at later time points. Since the dye in the live/dead assay stains dead bacteria due to a compromised membrane, the observed staining could be related to the interaction of the phenolic compounds with the peptidoglycan layer of the bacterial cell wall, ${ }^{69,73}$ altering the permeability of the cell wall without affecting the viability of the bacteria. ${ }^{75}$ In this regard, further investigations on the mechanisms behind the interactions of the coatings and the bacterial cells are needed to understand this phenomenon.

\section{Conclusions}

In summary, auto-oxidative tannic acid and pyrogallol coatings on titanium surfaces were shown to be non-toxic to primary human osteoblasts. The release of phenolic compounds from surfaces coated with TA for 2 and $24 \mathrm{~h}$ and with PG for $24 \mathrm{~h}$ induced a delay in osteoblast maturation. The same coatings exhibited anti-inflammatory potential by decreasing the gene expression of IL6. No release was detected from surfaces coated with PG for $2 \mathrm{~h}$, and these surfaces promoted osteoblast maturation and increased calcium deposition. The coated surface 
could not prevent bacterial colonisation and biofilm formation on the surfaces. However, the release of phenolic compounds from surfaces coated for $24 \mathrm{~h}$ had a strong effect on planktonic bacteria. The mechanism behind this effect remains unclear.

\section{Supporting information available}

Supporting information is available free of charge at doi: $10.1021 /$ acsbiomaterials.9b00566. Primer sequences for reference and target genes used in the study; illustration of sample mounting for release setup; dissipation shifts in coating stability test; contribution of temperature and buffer change on QCM-D signal; metabolic activity of hOB at $48 \mathrm{~h}$; bacterial luminescence curves from biofilm setup; SEM and live/dead images of biofilms formed during $12 \mathrm{~h}$ incubation for S. epidermidis and $2 \mathrm{~h}$ and $6 \mathrm{~h}$ for $S$. aureus; bacterial luminescence curves from release setup; description of the effect of dissolved and oxidised polyphenolic compounds on bacterial viability and growth

\section{Acknowledgements}

This work was supported by the Research Council of Norway (Grant 230258) and the Faculty of Dentistry, University of Oslo. The authors are grateful to Jessica Lönn-Stensrud for asking all the right questions and teaching us how to think more like a microbiologist.

\section{References}

1. Davies, J. E.; Hosseini, M. M., Histodynamics of Endosseous Wound Healing. In Bone Engineering, Davies, J. E., Ed. EM Squared Inc: Toronto, 2000; pp 1-14.

2. Beikler, T.; Flemmig, T. F., Implants in the Medically Compromised Patient. Crit. Rev. Oral Biol. Med. 2003, 14 (4), 305-316. DOI: 10.1177/154411130301400407.

3. Alsaadi, G.; Quirynen, M.; Komárek, A.; Van Steenberghe, D., Impact of Local and Systemic Factors on the Incidence of Oral Implant Failures, up to Abutment Connection. J. Clin. Periodontol. 2007, 34 (7), 610-617. DOI: 10.1111/j.1600-051X.2007.01077.x.

4. Johnsen, S. P.; Sørensen, H. T.; Lucht, U.; Søballe, K.; Overgaard, S.; Pedersen, A. B., PatientRelated Predictors of Implant Failure after Primary Total Hip Replacement in the Initial, Short- and Long-Terms. Bone Joint J. 2006, 88-B (10), 1303-1308. DOI: 10.1302/0301-620x.88b10.17399. 
5. Ihde, S.; Kopp, S.; Gundlach, K.; Konstantinović, V. S., Effects of Radiation Therapy on Craniofacial and Dental Implants: A Review of the Literature. Oral Surg. Oral Med. Oral Pathol. 2009, 107 (1), 56-65. DOI: 10.1016/j.tripleo.2008.06.014.

6. Gristina, A. G., Biomaterial-Centered Infection: Microbial Adhesion Versus Tissue Integration. Science 1987, 237 (4822), 1588-1595. DOI: 10.2307/1699782.

7. Busscher, H. J.; van der Mei, H. C.; Subbiahdoss, G.; Jutte, P. C.; van den Dungen, J. J. A. M.; Zaat, S. A. J.; Schultz, M. J.; Grainger, D. W., Biomaterial-Associated Infection: Locating the Finish Line in the Race for the Surface. Sci. Transl. Med. 2012, 4 (153), 153rv10. DOI: 10.1126/scitranslmed.3004528.

8. Costerton, J. W.; Stewart, P. S.; Greenberg, E. P., Bacterial Biofilms: A Common Cause of Persistent Infections. Science 1999, 284 (5418), 1318-1322. DOI: 10.1126/science.284.5418.1318.

9. Le Guehennec, L.; Soueidan, A.; Layrolle, P.; Amouriq, Y., Surface Treatments of Titanium Dental Implants for Rapid Osseointegration. Dent. Mater. 2007, 23 (7), 844-854.

10. Liu, X.; Chu, P. K.; Ding, C., Surface Modification of Titanium, Titanium Alloys, and Related Materials for Biomedical Applications. Mat. Sci. Eng. $R$ 2004, 47 (3-4), 49-121. DOI: 10.1016/j.mser.2004.11.001.

11. Lausmaa, J., Mechanical, Thermal, Chemical and Electrochemical Surface Treatment of Titanium. In Titanium in Medicine, Brunette, D. M.; Tengvall, P.; Textor, M.; Thomsen, P., Eds. Springer: Berlin Heidelberg, 2001; pp 231-266.

12. de Groot, K.; Wolke, J. G. C.; Jansen, J. A., Calcium Phosphate Coatings for Medical Implants. Proc. Inst. Mech. Eng. H J. Eng. Med. 1998, 212 (2), 137-147. DOI: 10.1243/0954411981533917.

13. Koyano, K.; Atsuta, I.; Jinno, Y., Anodized Surface and Its Clinical Performance. In Implant Surfaces and Their Biological and Clinical Impact, Wennerberg, A.; Albrektsson, T.; Jimbo, R., Eds. Springer: Berlin Heidelberg, 2015; pp 137-145. DOI: 10.1007/978-3-662-45379-7_10.

14. Morra, M., Biochemical Modification of Titanium Surfaces: Peptides and ECM Proteins. Eur. Cell. Mater. 2006, 12, 1-15.

15. Costa, F.; Carvalho, I. F.; Montelaro, R. C.; Gomes, P.; Martins, M. C. L., Covalent Immobilization of Antimicrobial Peptides (AMPs) onto Biomaterial Surfaces. Acta Biomater. 2011, 7 (4), 1431-1440. DOI: 10.1016/j.actbio.2010.11.005.

16. Zhao, L.; Chu, P. K.; Zhang, Y.; Wu, Z., Antibacterial Coatings on Titanium Implants. J. Biomed. Mater. Res. B 2009, 91B (1), 470-480. DOI: 10.1002/jbm.b.31463.

17. Goodman, S. B.; Yao, Z.; Keeney, M.; Yang, F., The Future of Biologic Coatings for Orthopaedic Implants. Biomaterials 2013, 34 (13), 3174-3183. DOI: 10.1016/j.biomaterials.2013.01.074.

18. Wei, Q.; Haag, R., Universal Polymer Coatings and Their Representative Biomedical Applications. Mater. Horiz. 2015, 2 (6), 567-577. DOI: 10.1039/C5MH00089K.

19. Cao, L.; Qu, Y.; Hu, C.; Wei, T.; Zhan, W.; Yu, Q.; Chen, H., A Universal and Versatile Approach for Surface Biofunctionalization: Layer-by-Layer Assembly Meets Host-Guest Chemistry. Adv. Mater. Inter. 2016, 3 (18), 1600600. DOI: 10.1002/admi.201600600.

20. Yu, L.; Cheng, C.; Ran, Q.; Schlaich, C.; Noeske, P.-L. M.; Li, W.; Wei, Q.; Haag, R., Bioinspired Universal Monolayer Coatings by Combining Concepts from Blood Protein Adsorption and Mussel Adhesion. ACS Appl. Mater. Inter. 2017, 9 (7), 6624-6633. DOI: 10.1021/acsami.6b15834.

21. Chen, S.; Xie, Y.; Xiao, T.; Zhao, W.; Li, J.; Zhao, C., Tannic Acid-Inspiration and Post-Crosslinking of Zwitterionic Polymer as a Universal Approach Towards Antifouling Surface. Chem. Eng. J. 2018, 337, 122-132. DOI: 10.1016/j.cej.2017.12.057.

22. Liu, Y.; Ai, K.; Lu, L., Polydopamine and Its Derivative Materials: Synthesis and Promising Applications in Energy, Environmental, and Biomedical Fields. Chem. Rev. 2014, 114 (9), 5057-5115. DOI: $10.1021 /$ cr400407a.

23. Barclay, T. G.; Hegab, H. M.; Clarke, S. R.; Ginic-Markovic, M., Versatile Surface Modification Using Polydopamine and Related Polycatecholamines: Chemistry, Structure, and Applications. Adv. Mater. Inter. 2017, 4 (19), 1601192. DOI: 10.1002/admi.201601192. 
24. Ryu, J. H.; Messersmith, P. B.; Lee, H., Polydopamine Surface Chemistry: A Decade of Discovery. ACS Appl. Mater. Inter. 2018, 10 (9), 7523-7540. DOI: 10.1021/acsami.7b19865.

25. Sileika, T. S.; Barrett, D. G.; Zhang, R.; Lau, K. H. A.; Messersmith, P. B., Colorless Multifunctional Coatings Inspired by Polyphenols Found in Tea, Chocolate, and Wine. Angew. Chem. Int. Ed. 2013, 52 (41), 10766-10770. DOI: 10.1002/anie.201304922.

26. Barrett, D. G.; Sileika, T. S.; Messersmith, P. B., Molecular Diversity in Phenolic and Polyphenolic Precursors of Tannin-Inspired Nanocoatings. Chem. Commun. 2014, 50 (55), 7265-7268. DOI: 10.1039/C4CC02961E.

27. Madhurakkat Perikamana, S. K.; Lee, S. M.; Lee, J.; Ahmad, T.; Lee, M.; Yang, H.-S.; Shin, H., Oxidative Epigallocatechin Gallate Coating on Polymeric Substrates for Bone Tissue Regeneration. Macromol. Biosci. 2019, 1800392. DOI: 10.1002/mabi.201800392.

28. Geißler, S.; Barrantes, A.; Tengvall, P.; Messersmith, P. B.; Tiainen, H., Deposition Kinetics of Bioinspired Phenolic Coatings on Titanium Surfaces. Langmuir 2016, 32, 8050-8060. DOI: 10.1021/acs.langmuir.6b01959.

29. Lamolle, S. F.; Monjo, M.; Lyngstadaas, S. P.; Ellingsen, J. E.; Haugen, H. J., Titanium Implant Surface Modification by Cathodic Reduction in Hydrofluoric Acid: Surface Characterization and in Vivo Performance. J. Biomed. Mater. Res. Part A 2009, 88A (3), 581-588. DOI: 10.1002/jbm.a.31898.

30. Ducy, P.; Schinke, T.; Karsenty, G., The Osteoblast: A Sophisticated Fibroblast under Central Surveillance. Science 2000, 289 (5484), 1501-1504. DOI: 10.1126/science.289.5484.1501.

31. Stein, G. S.; Lian, J. B.; Stein, J. L.; Van Wijnen, A. J.; Montecino, M., Transcriptional Control of Osteoblast Growth and Differentiation. Physiol. Rev. 1996, 76 (2), 593-629.

32. Monjo, M.; Ramis, J. M.; Rønold, H. J.; Taxt-Lamolle, S. F.; Ellingsen, J. E.; Lyngstadaas, S. P., Correlation between Molecular Signals and Bone Bonding to Titanium Implants. Clin. Oral Implants Res. 2013, 24 (9), 1035-1043. DOI: 10.1111/j.1600-0501.2012.02496.x.

33. Akira, S.; Hirano, T.; Taga, T.; Kishimoto, T., Biology of Multifunctional Cytokines: IL 6 and Related Molecules (IL 1 and TNF). FASEB J. 1990, 4 (11), 2860-2867. DOI: 10.1096/fasebj.4.11.2199284. 34. Yang, X.; Ricciardi, B. F.; Hernandez-Soria, A.; Shi, Y.; Pleshko Camacho, N.; Bostrom, M. P. G., Callus Mineralization and Maturation Are Delayed During Fracture Healing in Interleukin-6 Knockout Mice. Bone 2007, 41 (6), 928-936. DOI: 10.1016/j.bone.2007.07.022.

35. Dimitriou, R.; Tsiridis, E.; Giannoudis, P. V., Current Concepts of Molecular Aspects of Bone Healing. Injury 2005, 36 (12), 1392-1404. DOI: 10.1016/j.injury.2005.07.019.

36. Mountziaris, P. M.; Mikos, A. G., Modulation of the Inflammatory Response for Enhanced Bone Tissue Regeneration. Tissue Eng. Pt. B: Rev. 2008, 14 (2), 179-186. DOI: 10.1089/ten.teb.2008.0038.

37. Gabay, C., Interleukin-6 and Chronic Inflammation. Arthritis Res. Ther. 2006, 8 (2), S3. DOI: 10.1186/ar1917.

38. Okada, H.; Murakami, S., Cytokine Expression in Periodontal Health and Disease. Crit. Rev. Oral Biol. Med. 1998, 9 (3), 248-266. DOI: 10.1177/10454411980090030101.

39. Bodet, C.; Chandad, F.; Grenier, D., Cranberry Components Inhibit Interleukin-6, Interleukin8, and Prostaglandin E2 Production by Lipopolysaccharide-Activated Gingival Fibroblasts. Eur. J. Oral Sci. 2007, 115 (1), 64-70. DOI: 10.1111/j.1600-0722.2007.00415.x.

40. Ishimi, Y.; Miyaura, C.; Jin, C. H.; Akatsu, T.; Abe, E.; Nakamura, Y.; Yamaguchi, A.; Yoshiki, S.; Matsuda, T.; Hirano, T., IL-6 Is Produced by Osteoblasts and Induces Bone Resorption. J. Immunol. 1990, 145 (10), 3297-3303.

41. Kurihara, N.; Bertolini, D.; Suda, T.; Akiyama, Y.; Roodman, G. D., IL-6 Stimulates OsteoclastLike Multinucleated Cell Formation in Long Term Human Marrow Cultures by Inducing IL-1 Release. J. Immunol. 1990, 144 (11), 4226-4230.

42. Graves, D., Cytokines That Promote Periodontal Tissue Destruction. Journal of Periodontology 2008, 79 (8s), 1585-1591. DOI: 10.1902/jop.2008.080183.

43. Irwin, C. R.; Myrillas, T. T., The Role of IL-6 in the Pathogenesis of Periodontal Disease. Oral Dis. 1998, 4 (1), 43-47. DOI: 10.1111/j.1601-0825.1998.tb00255.x. 
44. Sims, N. A., Cell-Specific Paracrine Actions of IL-6 Family Cytokines from Bone, Marrow and Muscle That Control Bone Formation and Resorption. Int. J. Biochem. Cell Biol. 2016, 79, 14-23. DOI: 10.1016/j.biocel.2016.08.003.

45. Mundy, G. R., Osteoporosis and Inflammation. Nutr. Rev. 2007, 65, S147-S151. DOI: 10.1111/j.1753-4887.2007.tb00353.x.

46. Córdoba, A.; Satué, M.; Gómez-Florit, M.; Hierro-Oliva, M.; Petzold, C.; Lyngstadaas, S. P.; González-Martín, M. L.; Monjo, M.; Ramis, J. M., Flavonoid-Modified Surfaces: Multifunctional Bioactive Biomaterials with Osteopromotive, Anti-Inflammatory, and Anti-Fibrotic Potential. Adv. Healthc. Mater. 2015, 4 (4), 540-549. DOI: 10.1002/adhm.201400587.

47. Höök, F.; Kasemo, B.; Nylander, T.; Fant, C.; Sott, K.; Elwing, H., Variations in Coupled Water, Viscoelastic Properties, and Film Thickness of a Mefp-1 Protein Film During Adsorption and CrossLinking: A Quartz Crystal Microbalance with Dissipation Monitoring, Ellipsometry, and Surface Plasmon Resonance Study. Anal. Chem. 2001, 73 (24), 5796-5804. DOI: 10.1021/ac0106501.

48. Akagawa, M.; Shigemitsu, T.; Suyama, K., Production of Hydrogen Peroxide by Polyphenols and Polyphenol-Rich Beverages under Quasi-Physiological Conditions. Biosci. Biotechnol. Biochem. 2003, 67 (12), 2632-2640. DOI: 10.1271/bbb.67.2632.

49. Rojkind, M.; Domínguez-Rosales, J.-A.; Nieto, N.; Greenwel, P., Role of Hydrogen Peroxide and Oxidative Stress in Healing Responses. Cell. Mol. Life Sci. 2002, 59 (11), 1872-1891. DOI: 10.1007/pl00012511.

50. Bai, X.-C.; Lu, D.; Bai, J.; Zheng, H.; Ke, Z.-y.; Li, X.-m.; Luo, S.-q., Oxidative Stress Inhibits Osteoblastic Differentiation of Bone Cells by ERK and NF-KB. Biochem. Biophys. Res. Commun. 2004, 314 (1), 197-207. DOI: 10.1016/j.bbrc.2003.12.073.

51. Mody, N.; Parhami, F.; Sarafian, T. A.; Demer, L. L., Oxidative Stress Modulates Osteoblastic Differentiation of Vascular and Bone Cells. Free Radic. Biol. Med. 2001, 31 (4), 509-519. DOI: 10.1016/S0891-5849(01)00610-4.

52. Scalbert, A., Antimicrobial Properties of Tannins. Phytochemistry 1991, 30 (12), 3875-3883. DOI: 10.1016/0031-9422(91)83426-L.

53. Cushnie, T. P. T.; Lamb, A. J., Recent Advances in Understanding the Antibacterial Properties of Flavonoids. Int. J. Antimicrob. Agents 2011, 38 (2), 99-107. DOI: 10.1016/j.ijantimicag.2011.02.014. 54. Daglia, M., Polyphenols as Antimicrobial Agents. Curr. Opin. Biotechnol. 2012, 23 (2), 174-181. DOI: 10.1016/j.copbio.2011.08.007.

55. Taguri, T.; Tanaka, T.; Kouno, I., Antibacterial Spectrum of Plant Polyphenols and Extracts Depending Upon Hydroxyphenyl Structure. Biol. Pharm. Bull. 2006, 29 (11), 2226-2235. DOI: 10.1248/bpb.29.2226.

56. Gomez-Florit, M.; Pacha-Olivenza, M. A.; Fernández-Calderón, M. C.; Córdoba, A.; GonzálezMartín, M. L.; Monjo, M.; Ramis, J. M., Quercitrin-Nanocoated Titanium Surfaces Favour Gingival Cells against Oral Bacteria. Sci. Rep. 2016, 6, 22444. DOI: 10.1038/srep22444.

57. Payra, D.; Naito, M.; Fujii, Y.; Nagao, Y., Hydrophobized Plant Polyphenols: Self-Assembly and Promising Antibacterial, Adhesive, and Anticorrosion Coatings. Chem. Commun. 2016, 52, 312-315. DOI: $10.1039 /$ C5CC07090B.

58. Dhand, C.; Harini, S.; Venkatesh, M.; Dwivedi, N.; Ng, A.; Liu, S.; Verma, N. K.; Ramakrishna, S.; Beuerman, R. W.; Loh, X. J.; Lakshminarayanan, R., Multifunctional Polyphenols- and CatecholaminesBased Self-Defensive Films for Health Care Applications. ACS Appl. Mater. Inter. 2016, 8 (2), 12201232. DOI: 10.1021/acsami.5b09633.

59. Li, X.; Gao, P.; Tan, J.; Xiong, K.; Maitz, M. F.; Pan, C.; Wu, H.; Chen, Y.; Yang, Z.; Huang, N., Assembly of Metal-Phenolic/Catecholamine Networks for Synergistically Anti-Inflammatory, Antimicrobial, and Anticoagulant Coatings. ACS Appl. Mater. Inter. 2018, 10 (47), 40844-40853. DOI: 10.1021/acsami.8b14409.

60. Hancock, V.; Dahl, M.; Vejborg, R. M.; Klemm, P., Dietary Plant Components Ellagic Acid and Tannic Acid Inhibit Escherichia coli Biofilm Formation. J. Med. Microbiol. 2010, 59 (4), 496-498. DOI: doi:10.1099/jmm.0.013680-0. 
61. Jagani, S.; Chelikani, R.; Kim, D.-S., Effects of Phenol and Natural Phenolic Compounds on Biofilm Formation by Pseudomonas aeruginosa. Biofouling 2009, 25 (4), 321-324. DOI: 10.1080/08927010802660854.

62. Lin, M.-H.; Chang, F.-R.; Hua, M.-Y.; Wu, Y.-C.; Liu, S.-T., Inhibitory Effects of 1,2,3,4,6-pentaO-galloyl- $\beta$-D-glucopyranose on Biofilm Formation by Staphylococcus aureus. Antimicrob. Agents Chemother. 2011, 55 (3), 1021-1027. DOI: 10.1128/aac.00843-10.

63. Payne, D. E.; Martin, N. R.; Parzych, K. R.; Rickard, A. H.; Underwood, A.; Boles, B. R., Tannic Acid Inhibits Staphylococcus aureus Surface Colonization in an IsaA-Dependent Manner. Infect. Immun. 2013, 81 (2), 496-504. DOI: 10.1128/iai.00877-12.

64. Lee, J.-H.; Park, J.-H.; Cho, H. S.; Joo, S. W.; Cho, M. H.; Lee, J., Anti-Biofilm Activities of Quercetin and Tannic Acid against Staphylococcus aureus. Biofouling 2013, 29 (5), 491-499. DOI: 10.1080/08927014.2013.788692.

65. Sendamangalam, V.; Choi, O. K.; Kim, D.; Seo, Y., The Anti-Biofouling Effect of Polyphenols against Streptococcus mutans. Biofouling 2011, 27 (1), 13-19. DOI: 10.1080/08927014.2010.535897.

66. Powers, M. E.; Smith, P. A.; Roberts, T. C.; Fowler, B. J.; King, C. C.; Trauger, S. A.; Siuzdak, G.; Romesberg, F. E., Type I Signal Peptidase and Protein Secretion in Staphylococcus epidermidis. J. Bacteriol. 2011, 193 (2), 340-348. DOI: 10.1128/jb.01052-10.

67. Morán, A.; Gutiérrez, S.; Martínez-Blanco, H.; Ferrero, M. A.; Monteagudo-Mera, A.; Rodríguez-Aparicio, L. B., Non-Toxic Plant Metabolites Regulate Staphylococcus Viability and Biofilm Formation: A Natural Therapeutic Strategy Useful in the Treatment and Prevention of Skin Infections. Biofouling 2014, 30 (10), 1175-1182. DOI: 10.1080/08927014.2014.976207.

68. Payne, D. Disruption of the Staphylococcus aureus Biofilm by IsaA. Doctoral thesis, University of Michigan, 2015.

69. Dong, G.; Liu, H.; Yu, X.; Zhang, X.; Lu, H.; Zhou, T.; Cao, J., Antimicrobial and Anti-Biofilm Activity of Tannic Acid against Staphylococcus aureus. Nat. Prod. Res. 2018, 32 (18), 2225-2228. DOI: 10.1080/14786419.2017.1366485.

70. Arakawa, H.; Maeda, M.; Okubo, S.; Shimamura, T., Role of Hydrogen Peroxide in Bactericidal Action of Catechin. Biol. Pharm. Bull. 2004, 27 (3), 277-281. DOI: 10.1248/bpb.27.277.

71. Stapleton, P. D.; Shah, S.; Ehlert, K.; Hara, Y.; Taylor, P. W., The B-Lactam-Resistance Modifier (-)-Epicatechin Gallate Alters the Architecture of the Cell Wall of Staphylococcus aureus. Microbiology 2007, 153 (7), 2093-2103. DOI: doi:10.1099/mic.0.2007/007807-0.

72. Cushnie, T. P. T.; Hamilton, V. E. S.; Chapman, D. G.; Taylor, P. W.; Lamb, A. J., Aggregation of Staphylococcus aureus Following Treatment with the Antibacterial Flavonol Galangin. J. Appl. Microbiol. 2007, 103 (5), 1562-1567. DOI: 10.1111/j.1365-2672.2007.03393.x.

73. Cui, Y.; Oh, Y. J.; Lim, J.; Youn, M.; Lee, I.; Pak, H. K.; Park, W.; Jo, W.; Park, S., AFM Study of the Differential Inhibitory Effects of the Green Tea Polyphenol (-)-Epigallocatechin-3-Gallate (EGCG) against Gram-Positive and Gram-Negative Bacteria. Food Microbiol. 2012, 29 (1), 80-87. DOI: 10.1016/j.fm.2011.08.019.

74. Wiedmer, D.; Petersen, F. C.; Lönn-Stensrud, J.; Tiainen, H., Antibacterial Effect of Hydrogen Peroxide-Titanium Dioxide Suspensions in the Decontamination of Rough Titanium Surfaces. Biofouling 2017, 33 (6), 451-459. DOI: 10.1080/08927014.2017.1322585.

75. Kirchhoff, C.; Cypionka, H., Propidium Ion Enters Viable Cells with High Membrane Potential During Live-Dead Staining. J. Microbiol. Methods 2017, 142, 79-82. DOI: 10.1016/j.mimet.2017.09.011. 